\title{
International knowledge transfer in religious education? The example of Germany and South Africa as test case
}

\begin{tabular}{|c|c|}
\hline \multicolumn{2}{|c|}{$\begin{array}{l}\text { Author: } \\
\text { Friedrich Schweitzer }{ }^{1,2} \text { (1) }\end{array}$} \\
\hline \multicolumn{2}{|c|}{$\begin{array}{l}\text { Affiliation: } \\
{ }^{1} \text { Faculty of Protestant } \\
\text { Theology, University of } \\
\text { Tübingen, Tübingen, Germany }\end{array}$} \\
\hline \multicolumn{2}{|c|}{$\begin{array}{l}{ }^{2} \text { Department of Practical } \\
\text { Theology, Faculty of } \\
\text { Theology, University } \\
\text { of Pretoria, Pretoria, } \\
\text { South Africa }\end{array}$} \\
\hline \multicolumn{2}{|c|}{$\begin{array}{l}\text { Research Project Registration: } \\
\text { Project Leader: Y. Dreyer (I) } \\
\text { Project Number: } 2546930\end{array}$} \\
\hline \multicolumn{2}{|c|}{$\begin{array}{l}\text { Description: } \\
\text { Prof. Dr Friedrich Schweitzer } \\
\text { is participating in the } \\
\text { research project 'Gender } \\
\text { Studies and Practical } \\
\text { Theology Theory Formation', } \\
\text { directed by Prof. Dr Yolanda } \\
\text { Dreyer, Department of } \\
\text { Practical Theology, Faculty } \\
\text { of Theology, University of } \\
\text { Pretoria. }\end{array}$} \\
\hline \multicolumn{2}{|c|}{$\begin{array}{l}\text { Corresponding author: } \\
\text { Friedrich Schweitzer, } \\
\text { friedrich.schweitzer@ } \\
\text { uni-tuebingen.de }\end{array}$} \\
\hline \multicolumn{2}{|c|}{$\begin{array}{l}\text { Dates: } \\
\text { Received: } 29 \text { Apr. } 2019 \\
\text { Accepted: } 05 \text { June } 2019 \\
\text { Published: } 14 \text { Aug. } 2019\end{array}$} \\
\hline \multicolumn{2}{|c|}{$\begin{array}{l}\text { How to cite this article: } \\
\text { Schweitzer, F., 2019, } \\
\text { 'International knowledge } \\
\text { transfer in religious } \\
\text { education? The example of } \\
\text { Germany and South Africa as } \\
\text { test case', HTS Teologiese } \\
\text { Studies/Theological Studies } \\
75(4), \text { a5518. https://doi.org/ } \\
\text { 10.4102/hts.v75i4.5518 }\end{array}$} \\
\hline \multicolumn{2}{|l|}{ Read online: } \\
\hline 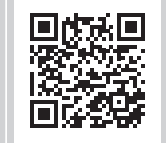 & $\begin{array}{l}\text { Scan this QR } \\
\text { code with your } \\
\text { smart phone or } \\
\text { mobile device } \\
\text { to read online. }\end{array}$ \\
\hline
\end{tabular}

The focus of this article is on international knowledge transfer in religious education as it has been proposed by a recent Manifesto in Europe. Readers are introduced to this Manifesto which also is the starting point of the article. The example of Germany and South Africa is used as a test case for the understanding of international knowledge transfer. The author analyses this understanding on the background of general considerations, among others, concerning unilateral and bilateral forms of transfer, but also the meaning of empirical research in this context before he discusses three examples for German religious education learning from South Africa: human dignity, justice and reconciliation. In the final section of this article, the results of these discussions are connected with the question of what they imply for the understanding of international knowledge transfer in religious education. The author argues for a complex approach which entails a careful balance between the idea of sharing knowledge and doing justice to the contextual nature of research results in the field of religious education.

Keywords: Knowledge transfer; Religious education; Internationalisation; Research; International cooperation.

\section{Introduction}

This article makes the new European discussion on international knowledge transfer in religious education its starting point. This discussion has recently led to a Manifesto to which readers will be introduced in the following (cf. Manifesto 2019). The key idea behind this Manifesto is to strengthen international cooperation in religious education by focusing on the aspect of sharing knowledge. The special emphasis of the present article is the attempt to test and further elaborate the understanding of international knowledge transfer in religious education presented in the Manifesto by applying it to the example of Germany and South Africa. The aim is to find out more about what international knowledge transfer in religious education may mean when this idea is connected to concrete countries instead of the abstract idea of internationalisation. Moreover, the question is raised if international knowledge transfer should be understood as a unilateral or as a bilateral process.

The concept of international knowledge transfer has become quite popular, at least in academic contexts in Europe. The European Union, for example, has started several programmes like the so-called 'Erasmus+' programme, which supports the temporary mobility of academic personnel, among others, as one way of transferring knowledge from one country to another. Moreover, this concept is closely connected to general demands for internationalisation in academic work, for example, by taking account of international literature or, with more emphasis, by international cooperation in research projects.

In this context, the example of Germany and South Africa seems to be especially promising in a number of respects. Firstly, the choice of this example involves two countries which are fairly different in many ways.

Discussing possible processes of transfer, such differences are always of special interest in that they may entail special challenges which otherwise would remain undetected. Secondly, there has been a continued relationship between the two countries, among others, in the field of theology, including practical theology and religious education. Thirdly, there is the hope that new insights can be gained

Note: HTS 75th Anniversary Maake Masango Dedication.

Copyright: ( 2019. The Authors. Licensee: AOSIS. This work is licensed under the Creative Commons Attribution License. 
by extending the discussion on international knowledge transfer beyond Europe in order to make it truly international. Finally, in terms of practical motivation and feasibility of the attempt, the author of this article who lives and works in Germany has, at the same time, a continued interest in the collaboration with colleagues from South Africa.

Therefore, there are a number of reasons for considering the relationship between German and South African religious education as a suitable and attractive test case. But before that, the understanding of international knowledge transfer in religious education must be explained in more detail.

\section{A new idea and discussion: International knowledge transfer in the field of religious education}

In fall 2018, a group of colleagues from five different European countries under the leadership of Prof. Dr Friedrich Schweitzer (University of Tübingen) and Dr Peter Schreiner (Comenius Institute, Münster, Germany) came together to discuss the idea of international knowledge transfer in the field of religious education. Members of the group were Benjamin Ahme (University of Tübingen), Prof. Dr Jenny Berglund (Stockholm University), Dr Yauheniya Danilovich (University of Münster), Dr Jonathan Doney (University of Exeter), Prof. Dr David Käbisch (University of Frankfurt), Prof. Em Dr Siebren Miedema (VU Amsterdam), Prof. Dr Hubertus Roebben (University of Bonn) and Asst. Prof. Dr Athanasios Stogiannidis (Aristotle University of Thessaloniki). In January 2019, the group published a 'Manifesto for Discussion' titled 'International Knowledge Transfer in Religious Education'. In the following, I want to summarise this text and also quote some of its key passages. ${ }^{1}$

The manifesto begins with a number of challenges:

- 'International knowledge transfer is an ideal which has come to play an increasingly important role in academia as well as in politics.

- The observation of increasing internationalization also applies to the academic discipline of religious education.

- Yet there also is the observation that religious education has not reached the point at which one could speak of an integrated field of research'. (Manifesto 2019:1-2)

In other words, religious education is seen here as stuck between demands for internationalisation on the one hand and not having achieved understandings of research which can be shared internationally on the other hand. In the Manifesto, the challenges quoted above are explained and discussed in more detail which cannot be rendered here. The following passages are especially important in the present context (Manifesto 2019):

It seems to be the rare exception that international groups of researchers in academic religious education would be working on

1.The complete text of the Manifesto can be found at: https://comenius.de/themen/ Evangelische-Bildungsverantwortung-in-Europa/international-knowledge-transferEvangelische-Bildungsverantwortung-in-Europa/international-knowledge-transf
in-religious-education.php. Page numbers in the text refer to this document. certain problems and even more, that the solutions for certain problems or at least the analysis of such problems offered by individuals or groups in the field would become part of the common cumulative knowledge upon which religious education should build in the future. Can religious education be viewed, at least in part, as a research discipline producing results which are of international importance for both, theoretical and empirical insights and also in terms of their applicability in practices of religious education? (p. 2)

and:

In many countries, there is a strong tendency towards developing religious education as a field of research of its own right. Religious education strives to be more than the application of research done in other fields. Moreover, there have been discussions not only on research results but also on methodologies as well as on criteria for research (although this is probably more true for European countries than, for example, the United States of America). At the same time, it certainly is not the rule that research results on religious education are considered of interest beyond the given country. Much religious education literature is not even read outside the national contexts. Many contributions are published only in the vernacular and there is no encouragement in religious education to learn or to use foreign languages, with the exception of English. Yet only a very small portion of knowledge pertaining to religious education has been published in English. This is true for many countries, among them, for example, Germany, Austria and Switzerland. Although there have been attempts to publish more in English, for example, in the Scandinavian countries, the general presumption in religious education still seems to be that research results from one country are not of interest or importance in other countries or that they are not transferable due to their context-dependency. For the advancement of religious education as an academic discipline but, ultimately, also for the practice of religious education, this is a serious obstacle which should no longer go unaddressed. (pp. 2-3)

In these passages, obviously the idea of 'common cumulative knowledge' is pivotal. In other words, the question is if the knowledge - or the research results - produced by religious education research can be understood to consist of insights which have proven to be correct and can therefore be taken for granted in the future independently of their origins. This understanding and expectation which appears to have guided the natural sciences as well as, to a lesser extent, the social sciences would stand in stark contrast to a wide-spread lack of interest in research results from other countries, which can be observed in the field of religious education.

As a consequence of such critical observations, a number of suggestions are advanced in the Manifesto. In the present context, the following questions raised for further discussion are especially relevant:

- 'Should the validity of knowledge in religious education be considered general/universal or should it be seen as particular and regionally bound?

- Is this knowledge valid only in one country or is it valid internationally, independently of its national context of discovery? 
- And what type of knowledge is transferred with what normative status?

- Who might possibly benefit from it?' (Manifesto 2019:3)

The Manifesto also describes a number of initiatives (and the present article can be considered as one way of responding to these suggestions as well). The most pertinent passage for the following will be the last quote from the Manifesto (2019):

Initiatives for sharing knowledge: Since some concepts of 'transfer' seem to imply unilateral relationships or even hierarchies between those who are in possession of a certain knowledge and those who should receive it, concepts like 'sharing' or 'exchanging' knowledge appear to be more applicable to the cooperative spirit characteristic of the field of religious education. What is decisive, however, is that initiatives are needed which follow the format of truly sharing knowledge, i.e. of investigating how different insights concerning a certain task or problem, for example, of successful teaching fit together. (p. 5)

The critical reference to unilateral understandings of international knowledge transfer is an important starting point for my considerations in the following. Has there been any kind of knowledge transfer in religious education between Germany and South Africa? And if so, how can it be characterised? Can the understandings of international knowledge transfer advanced by the Manifesto be fruitfully applied in this case?

\section{International knowledge transfer in religious education between Germany and South Africa: General considerations}

Any consideration of international knowledge transfer concerning European and African countries has to be aware of the wider historical background of the particular relationship between such countries. In other words, the background of colonial history and colonialism has to be included. Although South Africa never was a German colony, neighbouring South West Africa (today's Namibia) was related to Germany as a colony from 1884 to 1919 . At that time, most processes of knowledge transfer were considered strictly unilateral. Europe was supposed to be the centre of knowledge, while Africa was viewed at best as a recipient of knowledge (if, given the general racism of the time, Africans were even considered capable of successfully acquiring socalled advanced Western knowledge).

The present article, however, is not about historical times and will not focus on colonialism. Yet the question of unilateral or bilateral (or multilateral) processes of international knowledge transfer must be understood with a constant eye to the historical legacies and with the new sensitivity that has come with the critical approach of post-colonialism (for the German discussion, see Nehring \& Tielesch 2013, 2018). In certain ways, the Manifesto quoted above testifies to such sensitivities by taking a critical stance towards unilateral conceptions of knowledge transfer, which still appear to be dominant in certain areas. Against this background, the idea of sharing or exchanging knowledge proposed in the Manifesto indeed seems much more appropriate than possible unilateral understandings of knowledge transfer.

Especially in theology, there have been many examples of international exchange between Germany and South Africa at a personal level. Concerning practical theology and religious education (as well as other fields of theology), a number of South African scholars hold degrees from German universities or have been part of international research initiatives which involved researchers from different countries, for example, in the case of research on human rights which was one of the most recent initiatives of this kind (cf. Van der Ven, Dreyer \& Pieterse 2005). Moreover, international associations like the International Academy of Practical Theology (IAPT), the International Seminar on Religious Education and Values (ISREV) or the International Society for Empirical Research in Theology (ISERT) have operated as meeting grounds for many scholars, among others, from South Africa and Germany, also with conferences being held in both countries. These associations are of special interest in the present context because they have taken a clear stand against discriminatory views and are demanding and supporting collegial relationships independently of the members' countries of origin. Their guiding idea is encounter and exchange based on mutuality instead of superiority and inferiority.

While the international associations mentioned above, which came into existence 30-40 years back, should indeed be considered encouraging examples, they still have not reached the decisive point that the Manifesto is aiming for, that is, the point at which knowledge gained in one place is taken to be a valid contribution at another place and when religious education can be considered an integrated field of research characterised by the joint effort of researching this field. The ideas of encounter and exchange often seem to only refer to meeting new colleagues, gaining new impressions and ideas or receiving new insights in situations which are different from one's own while there is no transfer of knowledge involved, at least not in the sense this concept seems to imply in other fields of research. As will be explained in more detail below, the absence of international knowledge transfer can create serious obstacles for international cooperation.

Yet is such a knowledge transfer even possible in a field like religious education? Are practical fields of work just too contextual and therefore never really open to the appropriation of knowledge which comes from different contexts?

This question is of key concern for any kind of international cooperation in religious education. If the influence of context is indeed so strong that there can be no really shared knowledge because contextually bound knowledge can only be used in certain places, such cooperation would be deemed to remain very limited from the beginning. 
Cooperation is hardly feasible without relying on some kind of shared knowledge. Without such a shared basis, cooperation may mean working side by side but not working together. Most of all, the aim of contributing to the advancement of a common field of research would, for the most part, be in vain.

Consequently, the demand for shared knowledge can hardly be rejected. Yet such a demand is like a wish in that it cannot create its own fulfilment. Can empirical research help to overcome the boundaries arising from the contextual boundedness of knowledge?

The question of transferability or generalisability of research results is indeed much discussed in the context of empirical research. By their very nature, valid empirical results imply that they can be generalised at least to a certain degree. Yet there also is the issue of representativity of data and research results to be considered. Generalisability is premised on working with samples that are representative for the population or, in the case of international and comparative research, for the different populations involved (for an example concerning religious education, see the international study on confirmation work, Schweitzer et al. $2015,2017)$. In the fields of the social sciences and educational research, results cannot be generalised beyond the populations from which representative samples have been drawn. In other words, empirical results which would be valid for both Germany and South Africa would require a respective data base and samples as well as an analysis of the data which shows that the results are in fact the same for both countries. It is obviously not very likely that this will be the case, at least not, for example, with religious or value orientations, which may be expected to vary with the respective cultural contexts (for a recent example from Germany referring to religious and values orientations, see Schweitzer et al. 2018). The contextuality of knowledge cannot be overcome by just relying on empirical research approaches, unless these approaches are developed in such a way that they can fit the specific demands and challenges of international research.

Yet in religious education as opposed to sociology, other types of empirical research, which refer more to the individual than the social or societal level, are also important. One example could be the use and usefulness of certain teaching methods which can be tested in different contexts like German schools and South African schools. For example, can biblical parables be taught in the same way with German and with South African children and adolescents? Will the pupils in the two countries experience similar difficulties with metaphoric language? And what strategy is most effective in overcoming such difficulties? To my knowledge, very little empirical work has been conducted on such questions so far (cf. the recent overview: Schweitzer \& Boschki 2018). Consequently, it might be worthwhile in the future to pursue such concrete questions in collaborative international research.
This suggestion should also be seen against the background of recent critical discussions on the school subject of Religious Education, for example, in the United Kingdom (cf. Conroy et al. 2013; Commission on Religious Education 2018). One problematic factor in this respect is the lack of well-founded research results concerning the effects, among others, of certain teaching and learning strategies (cf. Schweitzer \& Boschki 2018; concerning non-formal religious education, see Schweitzer, Ilg \& Schreiner 2019). It would be extremely helpful if teachers would no longer have to exclusively rely on their personal experiences in designing their lessons (even if personal experiences will certainly continue to play a decisive role in education).

In summary, the well-founded and convincing wish for shared knowledge in religious education appears to find its limits in the contextual nature of the knowledge which is used in religious education. At the same time, the general assumption of contextuality which at least prima facie holds true for certain kinds of knowledge, for example, religious orientations of youth, has so far not been tested in any detail as the example of teaching methods shows. This is one of the reasons why the Manifesto's question about the actual kinds of knowledge which may be transferred could be of crucial importance. The answer to this question could lead to the identification of transferable and non-transferable knowledge and, through this, also to a more specific understanding of shared knowledge in the field of religious education.

However, such general considerations necessarily remain abstract. This is why I want to discuss some more concrete examples in a second step.

\section{German religious education learning from South Africa: Human dignity - justice - reconciliation}

Looking for examples which might allow for insights into forms of international knowledge transfer in religious education beyond the traditionally unilateral relationships between Europe and Africa, three examples come to mind from a German perspective, which demonstrate how experiences and insights from South Africa have actually had a strong and lasting influence on religious education in Germany. In this section, these examples will be discussed in this particular perspective, that is, against the background of the question concerning their influence on religious education in Germany and also concerning what this influence implies for the understanding of international knowledge transfer in this field. It will not be possible here, however, to demonstrate such influences or learning effects in any detail, for example, by evaluating syllabi or textbooks used in German schools.

Human dignity is a classic topic of religious education, at least in the sense of its biblical roots in Genesis 1,26-27 (cf. Schweitzer 2016). Teaching about the human's likeness of God as stated in this passage does not imply, however, that the legal and political implications of human dignity were addressed in 
religious education. In fact, the inclusion of the political dimension did not become a new standard before the last decades of the 20th century. It was, among others, the apartheid system in South Africa that has put the issue of human dignity in its political dimensions on the agenda of German religious education since the 1970s and the 1980s. This is not to say that this system was the only motive for the new interest in human dignity - other experiences like National Socialism in Germany or the Socialist regimes in Eastern Europe and the USSR as well as the atrocities committed by the US army during the Vietnam War clearly also worked in this direction. Moreover, the political climate of that time certainly also contributed to the shift of focus concerning human dignity. Yet the South African apartheid system was especially challenging in that it was both a blatant violation of human dignity and a religious topic in that this system tried to legitimise itself by referring to the Christian faith. Through this reference to Christianity it also offered itself to critical theological analysis, although, of course, this had not been the effect intended by the supporters of apartheid.

The negative interest in the apartheid system's violations of human dignity explains why, in later years, South African spokesmen against apartheid, like Nelson Mandela and Bishop Tutu, also received much attention in German religious education. Their plea for social justice appeared so plausible and convincing because it could be interpreted and understood as overcoming some of the deepest forms of inhumanity. In this respect, they can be called encouraging and fascinating models which became important to young people in Germany who were introduced to them by religious education, at school as well as in church. In other words, experiences and insights from South Africa became important as negative examples - the violation of human rights and human dignity because of apartheid - as well as in a positive sense as contemporary interpretations of the meaning of justice.

My third example - reconciliation - is also related to the same context, but in this case to the post-apartheid situation. Reconciliation here mainly refers to the work of the Truth and Reconciliation Commission (TRC) South Africa, which was established as one of the attempts for overcoming the legacies of apartheid.

Several publications accompanied this process and gave it additional impact. This was especially true for Tutu's 'No future without forgiveness', which soon also became available in German translation (Tutu 2001). Nelson Mandela's publication 'Long walk to freedom', also available in German, had similar effects (Mandela 1994). As it is described by Tutu, the TRC worked with the idea that the truth especially concerning the crimes during the apartheid system had to be brought to light, openly confessed by the perpetrators and then, as far as possible, not revenged but forgiven. This was considered the only way for reconciliation to be achieved and for a new South Africa to find a basis for its future.

For religious education in Germany, this whole process was and indeed is - of so much vivid interest because it seems to make a biblical concept - reconciliation based on truth - come alive (for an ethical-theological analysis from a German perspective, see Wüstenberg 2004). It seems to directly re-enact Jesus' saying 'The truth will set you free' (Jh 8:32) and, through this, to transform it from a distant biblical word or world into part of today's reality. At the same time, the understanding of reconciliation on which the TRC was based is necessarily controversial - should the perpetrators really go without punishment? What does this imply for criminal acts in the future? Yet it is exactly such deep and challenging issues that make the work of the TRC a very suitable topic for religious education. If such issues make young people think about the complexity of questions like justice and punishment, the aims and effects of punishment, the possibilities for reconciliation, the role of faith and religion in such contexts, obviously a major task of religious education has been achieved.

Furthermore, while analysing the German interest in the work of the TRC one must also be aware that there were certain parallels between the situation in Germany and South Africa (see also Wüstenberg 2004). In 1989 and 1990, with the end of the Socialist state of East Germany and the ensuing German reunification, there was the question of how to deal with the injustices committed in the name of this non-democratic state. Most of all, the so-called State Security Service (Staatssicherheitsdienst - STASI) had developed an elaborate system of civilian people spying on other people. What could be appropriate ways of dealing with what these people had done? Not surprisingly, there were also questions of how the situation after 1990 compared to the time after 1945, the end of German National Socialism, again with many criminal acts committed during National Socialism and under the umbrella of an inhumane state and distorted legal system. The famous Nuremberg trials after 1945, which tried to deal with such crimes against humanity, as well as their shortcomings also became a reference point for the TRC (cf. Tutu 2001).

The parallels between the German situation after 1989 and post-apartheid and the connections between the Nuremberg trials and the TRC indicate that German views of the situation in South Africa involve a complex relationship between German and South African experiences in terms of historical parallels and connections. While these relationships cannot be examined here in any detail, another aspect has to be mentioned, which refers to the ways in which experiences and insights from South African were received and understood in Germany. From today's perspective it seems clear that German religious education learning from South Africa was not based simply on how things in South Africa really were, for example, in the view of South Africans, but on how things were actually perceived in Germany. To put it pointedly, one might even wonder if it was South Africa from which people in Germany tried to learn or if it was in fact rather their image of South Africa which they took to be reality. Both, apartheid as well as forgiveness and reconciliation look different when seen from distant Europe than for those who had to go through such experiences themselves and who had to deal with their aftermath close to 
home. This does not mean that German religious education would not have learnt from South Africa. Yet it seems obvious that such learning processes and transfers are quite complex and sometimes even contradictory, including special presuppositions in both countries, which should not be overlooked. The concept of transfer should consequently not be used in a naïve sense.

Unfortunately, no empirical studies concerning such questions are available, and concerning the situation of the 1990s and early 2000s, it is now too late to interview, for example, the adolescents of that period about their personal feelings and impressions. In terms of sharing knowledge, it would have been highly interesting to do joint empirical studies on how the TRC's work was viewed by young people in South Africa and Germany. It would also have been interesting to find out about their views of forgiveness - or the need for not forgiving - and to compare respective research results from South Africa and Germany. This could have also been a good starting point for bringing young people from the two countries into conversation with each other. Very likely our understanding of the processes involved in forgiving could have been strongly advanced by such research, and religious education in both countries could have greatly benefitted from this.

\section{What can be learnt for international knowledge transfer from the example of Germany and South Africa?}

As described in the Introduction, the idea of this article was to use the example of Germany and South Africa as a test case for the understanding of international knowledge transfer proposed by the Manifesto (cf. Manifesto 2019). In this concluding section, a number of observations will be summarised and some questions will be raised, which may be of interest for future work.

Firstly, the interdependence between cooperation and international knowledge transfer and shared knowledge in religious education has been confirmed. Academic cooperation presupposes that there are research results and insights based on them which are of importance to all partners of the cooperation, independently of their countries of origin. Otherwise only a very limited exchange of perspectives could be reached which, at best, can stir one's imagination or inspire curiosity.

Secondly, in considering the two countries that are not only far away from each other in terms of geographical location but also very different in many other respects, it has also become clear that context plays an important role in all processes of knowledge transfer in religious education. Context can be interpreted as a severe limitation to possible knowledge transfer, in this case practical approaches must always be highly sensitive to respective contexts and this of course must also be reflected in research.
Approaches which are considered highly effective in one place may not work at all in other places. At the same time, however, it must also be stated that context cannot be the only consideration in that knowledge which is exclusively contextual cannot be shared with others or only in the sense of information about a foreign situation. Extreme understandings of contextuality seem to therefore exclude all possibilities of cooperation in research, which implies that a balance must be found between contextuality and sharing.

Thirdly, the idea of sharing knowledge makes sense, especially in trying to overcome traditional or colonial forms of unilateral knowledge transfer as they have to be called in the case of the relationship between Germany or Europe and South Africa. Yet again, colonial ways of thinking are still in the process of being overcome. It is not enough to state that bilateralism and fair exchange should take over from traditional unilateral forms of transfer. Postulates alone will not move people's thinking beyond colonial traditions and limitations. This is why a number of examples of how German religious education has actually learnt from South Africa were discussed in order to show that there have, in fact, been such learning effects. In the end of this discussion, however, the situation once more turned out to be complex and to some extent also puzzling. Was it really the South African situation that German religious education has learnt from or was it the German image of this situation which gave shape to all processes of interpretation and reception on the German side? A simple answer to this question is not possible. The transfer of ideas, images, interpretations and inspirations remains a complex and sometimes contradictory process which deserves to be researched itself.

Fourthly and finally, the question was asked about the role of empirical research in this context. This kind of research aims for what is called valid results that can be generalised. Can this validity be universal? Can it apply to different countries and to different parts of the world? According to the above considerations, this is not to be excluded, at least not a priori, but universally valid results would in fact require an equally universal data base and respective samples. At least in religious education, there have been few attempts to work in this direction, especially concerning practical questions of teaching and learning. In other words, it seems that not enough attempts have been made so far in order to really judge the limits and scope of empirical research in religious education as a shared international enterprise. Yet existing examples from other contexts suggest that the benefits of such research should not only be seen in universally valid research results but also in fruitful cooperation and in possibly contrasting results which have to be interpreted against the background of the particular situations in different countries. Empirical research will not escape all contextual limitations, but it should be taken seriously as one possibility for doing joint research in religious education. To say it again, contextuality and the demands of sharing knowledge must be carefully balanced, not only once but continuously, in order to make international knowledge transfer in religious education possible. 


\section{Acknowledgement}

\section{Competing interest}

The author declares that no competing interest exists.

\section{Author contributions}

I declare that I am the sole author of this research article.

\section{Funding}

This research received no specific grant from any funding agency in the public, commercial, or not-for-profit sectors.

\section{Data availability statement}

Data sharing is not applicable to this article as no new data were created or analysed in this study.

\section{Disclaimer}

The views and opinions expressed in this article are those of the authors and do not necessarily reflect the official policy or position of any affiliated agency of the authors.

\section{Ethical consideration}

This article followed all ethical standards for carrying out research without direct contact with human or animal subjects.

\section{References}

Commission on Religious Education, 2018, Final Report. Religion and worldviews: The way forward. A national plan for RE, RE Council, London.

Conroy, J.C., Lundie, D., Davis, R.A., Baumfield, V., Barnes, L.P., Gallagher, T. et al., 2013, Does religious education work? A multi-dimensional investigation, Bloomsbury, London \& New York.

Mandela, N., 1994, Der lange Weg zur Freiheit. Autobiographie, Frankfurt am Main, S. Fischer.

Manifesto, 2019, International knowledge transfer in religious education: A Manifesto for discussion, viewed 02 July 2019, from https://comenius.de/themen/ Evangelische-Bildungsverantwortung-in-Europa/international-knowledgetransfer-in-religious-education.php.

Nehring, A. \& Tielesch, S. (eds.), 2013, Postkoloniale Theologien. Bibelhermeneutische und kulturwissenschaftliche Beiträge, Stuttgart, Kohlhammer.

Nehring, A. \& Tielesch, S. (eds.), 2018, Postkoloniale Theologien 2. Perspektiven aus dem deutschsprachigen Raum, Stuttgart, Kohlhammer.

Schweitzer, F., 2016, 'Human dignity and education - a Protestant view', HTS Teologiese Studies/Theological Studies 72(4), a3436. https://doi.org/10.4102/hts.v72i4.3436.

Schweitzer, F. \& Boschki, R. (eds.), 2018, Researching religious education. Classroom processes and outcomes, Münster \& New York, Waxmann

Schweitzer, F., Ilg, W. \& Schreiner, P. (eds.), 2019, Researching non-formal religious education in Europe, Münster \& New York, Waxmann.

Schweitzer, F., Niemelä, K., Schlag, T. \& Simojoki, H. (eds.), 2015, Youth, religion and confirmation work in Europe: The second study, Gütersloher Verlagshaus, Gütersloh.

Schweitzer, F., Schlag, T., Simojoki, H., Tervo-Niemelä, K. \& Ilg, W. (eds.), 2017, Confirmation, faith, and volunteerism: A longitudinal study on Protestant adolescents in the transition towards adulthood. European perspectives, Gütersloher Verlagshaus, Gütersloh.

Schweitzer, F., Wissner, G., Bohner, A., Nowack, R., Gronover, M. \& Boschki, R., 2018, Jugend - Glaube - Religion. Eine Repräsentativstudie zu Jugendlichen im Religions- und Ethikunterricht, Münster \& New York, Waxmann.

Tutu, D., 2001, Keine Zukunft ohne Versöhnung, Düsseldorf, Patmos.

Van der Ven, J.A., Dreyer, J. \& Peterse, H., 2005, Is there a God of human rights? The complex relationship between human rights and religion: A South African case, Leiden, Brill.

Wüstenberg, R., 2004, Die politische Dimension der Versöhnung. Eine theologische Studie zum Umgang mit Schuld nach den Systemumbrüchen in Südafrika und Deutschland, Gütersloh, Gütersloher Verlagshaus. 